\title{
Niemann-Pick Disease, Type C2
}

National Cancer Institute

\section{Source}

National Cancer Institute. Niemann-Pick Disease, Type C2. NCI Thesaurus. Code

C126865.

Type C Niemann-Pick disease associated with a mutation in the gene NPC2, encoding Niemann-Pick C2 protein. 